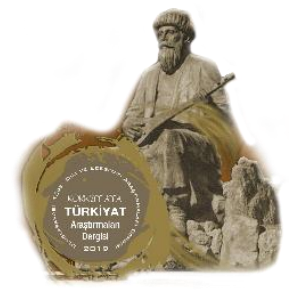

\author{
KORKUT ATA TÜRKIYYT ARAŞTIRMALARI DERGİII \\ Uluslararası Türk Dili ve Edebiyatı Araştırmaları Dergisi \\ The Journal of International Turkish Language $\mathcal{E}$ \\ Literature Research
}

\title{
Orta Oyununun Sosyolojik Yapısı ve Modern Türk Sanatına Etkisi
}

\section{Sociological Structure of The Middle Game and Its Effect on Modern Turkish Art}

\begin{abstract}
Orhan Aytuğ TOLU*
Öz

Geleneksel Türk tiyatrosunun türlerinden biri orta oyunudur. Bu türün dört yüzyıldan fazla bir geçmişi olduğu bilinmektedir. Kalabalık kişi kadrosu, kullandığı müzikal unsurları, bölümlere ayrılması ve kısıtlı şekilde kullandığı maddi malzemelerden dolayı modern tiyatronun yapısal özellikleriyle kesişmektedir. Orta oyunun yapısındaki sosyolojik göstergeler ise onu modern tiyatrodan ayırmakta, geleneksel olanın temsiline dönüştürmektedir. Kişi kadrosundaki kültürel ve sınıfsal temsiller, zennenin rol alması ve sabit bir mekânda oyunların sergilenmemesi hem Osmanlı toplum yapısını hem de Türklerin göçebe yaşama tarzını temsil etmektedir. Güldürürken düşündürmesi Türk sinemasının komedi anlayışını, bazı unsurlarının da modern Türk şiirini ve televizyon komedi programlarını etkilemiştir. Yazılı bir metninin olmaması eleştirel mizaha kapı aralamaktadır. Hem ordu seferlerinde hem meydanlarda halkın arasında oynanması savaş̧̧ı bir topluma motivasyon desteği sağlamaktadır. Orta oyunu tekçi ve dikey ilişkinin temsili olan modernitenin karşısında çoğulcu ve yatay ilişkinin taşıyıcısı olmuştur. Bu çalışmada semboller ve örtük iletilerle örülü orta oyununun tarihî ve şekil özelliklerinden yola çıkarak onun sosyolojik yapısı ve modern sanata etkileri ele alınmıştır.
\end{abstract}

Anahtar kelimeler: Geleneksel Türk tiyatrosu, orta oyunu, sosyolojik yapı, modernite, modern sanat.

\begin{abstract}
One of the genres of traditional Turkish theater is the orta oyunu. This species is known to have a history of more than four centuries. It intersects with the structural features of the modern theater due to its large cast, the musical elements it uses, its division into sections, and the limited use of material materials. The sociological indicators in the structure of the orta oyunu distinguish it from the modern theater and transform it into the representation of the traditional. Cultural and class representations in the staff, the role of the zenne and the absence of plays in a fixed place represent both the Ottoman society structure and the nomadic lifestyle of the Turks. Making you think while making you laugh has influenced the comedy understanding of Turkish cinema, and some of its elements have influenced modern Turkish poetry and television comedy programs. The lack of a written text opens the door to critical humor. Playing it among the people both in army campaigns and in the squares provides motivational support to a warrior society. Orta oyunu has been the bearer of pluralist and horizontal relations in the face of modernity, which is the representation of monist and vertical relations. In this study, its sociological structure and its effects on modern
\end{abstract}

\footnotetext{
* Yüksek Lisans Öğrencisi, İstanbul Kültür Üniversitesi, e-posta: aytugtolu@hotmail.com, ORCID: https://orcid.org/0000$\underline{0001-5915-2832 .}$
} 
art are discussed based on the historical and morphological features of the orta oyunu, which is woven with symbols and implicit messages.

Keywords: Traditional Turkish theater, orta oyunu, sociological structure, modernity, modern art.

\section{Giriş}

Görme yeri anlamına gelen "theatron" sözcüğünden türetilmiş bir sanat dalı olan tiyatro, seyircilerin karşısında oyuncuların bir sahnede canlandırdığı gösteridir. Bu sanat dalının tarihteki ilk örnekleri Yunan toplumunda görülür. Antik Yunan'da bağ bozumu zamanında düzenlenen Dynosisos şenliklerinde ilk tiyatro oyunları sergilenir. Tiyatro bu veçheyle dinsel bir törenin ürünü olarak tarih sahnesinde zuhur eder. Dinsel törenlerde gelişerek yoluna devam eden tiyatro günümüze kadar gelir. Tiyatro, bir gösteri olmaktan öte yetenek gerektiren bir sanattır. İlk tiyatro eserleri yazılı bir metin çerçevesinde icra edilmiştir. Bu icra edişte oyuncular ve koro önemli misyonlar üstlenir. Günümüz tiyatro salonlarının mimari yapısı antik Yunan tiyatrolarının oynandığı amfi tiyatrolardan esinlenir. Bu tarz bir mimari yapıda oyunun sergilenmesi toplumsal anlamda halkın da dayanışmasını ve sosyalleşmesini sağlar. Tiyatro, ilk olarak trajedi türünde şekillenir; ilerleyen çağlarda komedi ve dram türleriyle yolculuğuna devam eder.

Orta Çă̆'ın karanlık devrinden sonra tiyatro gelişimine devam etmiştir. Bu karanlık dönem tiyatro türünün gelişimini de engellemiştir. Batı' da Shakespeare, Moliere, Cornell gibi tiyatro yazarlarıyla bu sanat dalı Aydınlanma'nın da etkisiyle tekrar gündeme gelir. Batı dünyasında tiyatronun gelişimi bu şekilde ilerlerken Osmanlı toplumunda da Batılı tarzda ilk tiyatro ürünleri görülmeye başlanır. Askerî okullarda 3. Selim'in ıslahatları çerçevesinde ilk Fransızca dersleri verilmeye başlanır ve 2. Mahmut devrinde Tercüme Odaları açılır. Bu kurumda Fransızca öğrenen gençlerin Avrupa'ya yollanarak orada eğitim almaları ve yenilikleri yakından takip etmeleri hedeflenir. Tanzimat Fermanı'nın oluşturduğu modernleşme atmosferinde Batı'ya gönderilen ilk öğrencilerden biri Şinasi'dir. Şinasi, Avrupa'da aldığ1 eğitimin sonunda İstanbul'a döndüğünde sadece aldığı maliye eğitimini değil Batılı edebî türleri de beraberinde getirir. 1860'ta ilk Batılı tiyatro eserimiz olan Şair Evlenmesi'ni telif etmiştir. Günümüz modern Türk tiyatrosunun tohumu bu eserle atılır. Daha sonra bu gelişmeleri Namık Kemal'in yazdığı Vatan yahut Silistre eseri takip eder. Bu oyun ilk sahnelenen eserimiz olarak tarihe geçer. Bu yönüyle modern Türk tiyatrosu ortalama 160 yıllık bir geçmişe sahiptir. Modern tiyatro, Türk edebiyatı tarihinde genç sayılabilecek bir türdür.

Türk tiyatrosu için 1860 yeni bir eşiktir çünkü bu tarihte ve öncesinde geleneksel Türk tiyatrosunun türleri Osmanlı toplumunda icra ediliyordu. Karagöz, meddah, orta oyunu ve köy seyirlik oyunları geleneksel Türk tiyatrosu kapsamindadır. Bu dört tür içinde orta oyunu günümüz tiyatrosuna en yakın olanıdır diyebiliriz. Orta oyununun sahip olduğu özellikler bu benzerlikte etkilidir. Bu çalışmada geleneksel Türk tiyatrosu türlerinden biri olan orta oyununun tanımından ve şekil özelliklerinden hareketle bu türün sosyolojik yapısı, modern sanata etkileri, modernlikten ayrıldığı ve onunla kesiştiği veçheleri ele alınacaktır. Günümüzün tek kutuplu modern dünyasında globalleşme hüküm sürmektedir. Bu globalleşme ortamında ulusal kültürün korunması ulusların geleceği açısından şüphesiz önem arz etmektedir. Bu bağlamda geleneksel Türk tiyatrosu türleri hakkında araştırma/çalışma yapılması ulusal kültürün ayakta kalmasına katkı sağlayacaktır.

\section{Orta Oyununun Tanımı}

Orta oyunu etrafı seyircilerle çevrili bir alanda oynanmasından mütevellit bu ismi alır. Hakkında çeşitli görüşler olsa da ortak kanı meydanda/ortada oynandığı için bu ismi 
aldığı yönündedir. "Orta" günümüz modern tiyatrolarındaki sahnenin karşılığıdır değerlendirmesinde bulunabiliriz. İcra edilme mekânı olarak bir sahnesinin olması onu tiyatro türü olarak kabul etmede önemli bir adımdır çünkü tür, bir sunma biçimidir (Bauman, 2003). Bu mekânın, modern tiyatro türlerinin sahnesine göre üstün yanları vardır. Modern tiyatroların belirli bir binanın içinde sahne, izleyici ve koltuk düzenine sahip olması orta oyununa göre kısıtlı imkânlar kullandığını göstermektedir. Orta oyununda böyle bir kısıtlılık yoktur çünkü meydan/orta olabilecek/bulunabilecek her yerde bu oyunlar sergilenebilmektedir. Orta oyununun sahne sinırlarının sabit olmaması oyunculara icra imkânı açısından da özgürlük sağlar (Öztek, 2019). Orta oyunu oyuncularının geniş alanı kullanması, yeteneklerini sergileyebilmeleri için avantajlı bir durumdur.

\section{Orta Oyununun Tarihi}

Orta oyununun tarihî kökenlerine yönelik çeşitli görüşler dile getirilmiştir. Bunlar arasında savaşa giden orduya moral vermek için oynandığı, akıl hastanelerinde şifa vermek amacıyla sergilendiği, orta oyunun diğer adı olan "Zuhûrî Kolu"nun ortaya çıkmak manasına gelen "zuhûr" sözcüğünden geldiği gibi görüşler mevcut olsa da ortak kanının şu şekilde olduğu ifade edilebilir:

Orta oyununun "Yeniçeri ortaları"yla da ilgili olabileceği öne sürülmektedir. Çeşitli araştırmalarda oyuncuların orduyla birlikte savaşa gittikleri, savaş sirasında sultanı eğlendirdikleri, orta oyununun "ortada oynanan oyun" anlamina gelmediği, bunun yeniçeri ortalarından ve esnaf loncalarının ordu ve donanma eğlencelerinden çıktığı, 1826'da yeniçeriliğin kaldırılması üzerine, gezginci oyuncu topluluklarının "Karagöz" oyunlarının işlemesiyle oluştuğu anlatılmaktadır (...) Orta oyununun kesin biçimine kavuşup bu adı almasına, ilk kez II. Mahmut'un kızı Saliha Sultan'la, Rıfat Halil Paşa'nın dügüun şenliğini anlatan Saliha Sûrnâmesi'nde rastlanır (Sûrnâme-i Saliha). 1836 yılında, II. Mahmut'un çocukları Abdülmecit ile Abdülaziz' in sünnet dügüunleri ve Mihrimah Sultan'la Mehmet Sait Paşa'nın düğünleri için yapılan şenliği anlatan Lebîb Sûrnâmesi'nde, "Zuhûrî Kolu" nun sözü edilmektedir (Konur, 1995, s. 48).

Orta oyunu tabirine ilk defa Sultan II. Mahmut'un saltanat devrinde rastlanmaktadır. Orta oyunu adı ilk kez, 1833'te evlenen Saliha Sultan'ın dügüününü tasvir eden Esat Efendi'nin "Sûrnâme"sinde yer alır (Zobu, 2021). Zikredilen bu görüşlerden çıkarılan ortak tespit, oyunun adı geç bir dönemde bir yazılı eserde geçse de oyunun geçmişinin daha eski olduğudur.

\section{Orta Oyununun Şekil Özellikleri}

Orta oyunu bir meydanda oyuncuların halka gösteri yapması şeklinde icra edilir. “Karagöz'den çıktığı ileri sürülen orta oyununa 'kol oyunu, palanga' adları da verilir" (Töre, 2009, s. 2181). Karagöz oyununun perdeden meydana aktarılması yönünde bir alg1 mevcut olsa da bu tür, Karagöz'den birçok yönden farklıdır. "Canlı oyuncularla oynandığ1 için, bir gölge oyunu olan Karagöz'den temelde bir farklılığı bulunmasına karşılık bu iki tür arasında oyun dağarcığı, güldürme yöntemleri, kişiler ve yapı bakımından önemli benzerlikler bulunmaktadır" (Konur, 1995, s. 47). İki türün benzerlikleri olmasına rağmen orta oyununun Karagöz'den ayrıldığı en önemli farklılık canlı oyuncularla icrası edilmesidir.

Orta oyununun yapısını diyalog oluşturur ve başta Pişekâr olmak üzere, aktörler sirayla halkın ve onun temsili olan Kavuklu'nun önüne gelerek hesap vermekle mükelleftir; Karagöz gibi Kavuklu da halkın mümessilidir (Baltacığlu, 2021). Oyuncular 
meydana sırayla çıkarlar. Pişekâr Hacivat'ın, Kavuklu ise Karagöz'ün karşılığı gibidir. Kavuklu; oyunun baş komik kişisidir, dilimli bir kavuk giyer. Züppe bir tip olan Çelebi, kabadayı olan Tuzsuz Deli Bekir, mahallenin alığı Denyo, Kavuklu'nun arkasında Cüce, Kastamonulu Hırbo, Kayserili Bakkal, Trabzonlu Laz, Ermeni, Kürt, Arap, Yahudi, kadın kılığına girmiş Zenne, Rum, Rumelili oyunun diğer tipleridir. Bu kişilerin hepsi tip özelliği gösterir çünkü karakter özellikleri tek yönlü ve sabittir, değişime kapalıdırlar. Mesnevilerde ve halk hikâyelerinde kişiler tip olarak yer alır; iyiler hep iyi, kötüler hep kötü karaktere sahiptir. Orta oyunu, mesnevi ve halk hikâyelerinde kişilerin tip özelliği göstererek iyi ve kötünün temsiline dönüşmesi; Osmanlı toplumunda sanatın halka örnek olma motivasyonuyla hareket ettiğini göstermektedir. Kişilerin iyi ve kötü tip özelliği taşıması diyalektik çatışmanın da temsilidir. Oyunun kişi kadrosuna bağlı olarak gelenekselleşmiş icrası şu şekilde gerçekleşir:

Kayserili, "Gayseri' nin gızları, sırma gibi saçları" ile; Laz, "Hey tablalu tablalu, paraları turalu"; Kürt, "Karşıda Kürt evleri, yayılmış develeri"; Arnavut, "Tuna' da çırpar bezini, pek sevdim Bulgar kızını" ile çıkar; Balama, köhne bir polka tutturup fırıl fırıl döner; Yahudi, "Balat kapusundan yirdim içeri”yi söyleye söyleye zıp zıp zıplar; Tuzsuz Bekir, avaz avaz naraları basar; Aptal da curcunalı nağmelerle sersem sepet damlardı. Zurna çifte nara ahenge koyulmuş, fasıl başlamış. Evvela Pişekâr çıkagelir, meydanı bir kere dolaşır, iki eliyle halkı yerden selamlar, o günkü oyunun adını söyleyip mesela: "Kadının Fendi, Erkeği Yendi oyununun taklidini aldım, çal!" diyerek bir kenara çekilir, ardından Kavuklu kendine mahsus hava ile sökün ederek bir defa ortayı devrederdi. Pişekâr'la karşlıklı muhavereye girişirler. Nükteler, cinaslar, tekerlemeler veriştire veriştire hayli çene çalarlar. Derken efendim zenneler, çeşit çeşit taklitler gösterir, fasıl sona ererdi (Alus, 1950, s. 267).

Orta oyunu oyuncuları hayatlarını sadece oyunculukla sürdürmeyip geçimlerini sağlayabilmek için başka meslekleri de icra etmişlerdir. Orta oyununu icra eden oyuncuların yetişme şekli ve aldıkları oyunculuk eğitimi; küçük yaşta eğitime katılan çocukların usta-çırak ilişkisi içinde yetişmesi, daha sonra eğitim için girdikleri kollardan icazet alarak kendi kollarını -Han Kolu, Zuhûrî Kolu, Kirli Kol, Yaran Kolu, Çifte Kumrular Kolu gibi- kurması esasına dayanır (Konur, 1995, s. 51). Orta oyununun yükseliş devri Abdülaziz dönemine denk gelmektedir.

Orta oyununun oyuncu kadrosu geniştir. Köçek, Çengi, Hokkabaz, Kantocu, Cambaz eğlendiriciler arasında geçer. $\mathrm{Bu}$ eğlendiricilerin olması modern tiyatro türlerinden olan müzikale çok benzemektedir. Büyücü ve cinler de olağanüstü karakterler olarak oyunda yerini alır. "Orta oyunu natüralist tiyatro değil, sürrealist tiyatrodur; orta oyunu natüralist olan bütün unsurlardan sıyrılmış olan öz tiyatronun eski ve tarihî bir şeklidir" (Baltacıoğlu, 2021). Modern edebiyat akımlarından olan sürrealizmin geçmişine bakacak olursak orta oyunundan daha genç olduğu görülecektir. Nihal Türkmen orta oyunundaki bazı unsurların Batılı modern unsurlardan daha önce şekillendiğini şu şekilde izah etmiştir: “(...) Üç veya dört tarafı seyirci ile çevrili sahnede oynamak; şarkı, dans, koro gibi (lyrik) unsurları yeniden tiyatroya almak; daha rahat hareket etmek imkânını elde etmek için plastik sahnede zaten büsbütün gereksiz olan dekoru asgariye indirmek ve oyunu gerçeküstü bir mekânda tasavvur etmek gibi, absurde tiyatronun yöneldiği özellikler, esasen bizim tarihî tiyatromuzda bulunan unsurlardır" (Türkmen, 1971, s. 8). Orta oyununun modern tiyatro türü olmadığını dikkate alırsak modern tiyatro türlerinden önce keşfettiği özellikleri yazıya geçirmemesi ve bu özellikleri kuramsallaştırmaması onun geleneksel yapısından kaynaklanmaktadır. 
Mukaddime bölümünde oyun zurnacının çaldığı Pişekâr havasıyla başlar ve Pişekâr oyuna girer. Karagöz oyunundaki gibi Kavuklu ve Pişekâr'ın birbirini yanlış anladığ1 zıtlaşmaya dayanan komik kısım ise söyleşme anlamına gelen muhavere bölümüdür. Oyunun ana bölümü fasıldır, bu bölümde temel olaylar canlandırılır. Bitiş bölümünde Pişekâr izleyicilerden özür dileyip sonraki oyunun yeri ve zamanı hakkında bilgiler vererek oyunu nihayete erdirir. Orta oyununun icra biçimlerinin standart olmadığı, farklı icralarının olduğu bilinmektedir:

Araştırmacılar, orta oyununun zaman zaman tarz-1 kadimde (eski tarz) olduğu gibi curcunabazların dansıyla başladığını ama bunun bazen de yapılmadığını, daha sonra giriş ya da ön deyiş diye adlandırılan bir bölümle oyunun açıldığını, ardından muhavere ya da söyleşme denilen ve içinde "arzbar" ve "tekerleme" nin yer aldığı bölümün geldiğini, "arzbar"da Pişekâr ile Kavuklu'nun çeşitli söz hünerleriyle "çene yarıştırdıkları"nı, "tekerleme"de ise Kavuklu'nun gerçekte olmamış hatta biraz abartılı düşsel bir olayı gerçekmiş gibi Pişekâr'a "yutturduğu" nu ancak bu bölümlerden sonra ana olay ya da olaylar dizisinin yer aldığı "fasıl"a geçildiğini, oyunun "bitiş" ile sonlandırıldığını belirtmişlerdir (Balay, 2010, s. 95).

Orta oyununda yazılı bir metin yoktur. Sözlü geleneğin yeniden üretilmesi biçiminde icra edilen bir türdür. Halkın kendi üretimi olması hasebiyle orta oyunu anonim bir tür olma özelliği göstermektedir. Oyunun konusu belli eşyaların kullanılmasını gerektirse de dekor vardır diyemeyiz. Oyunun icra edildiği mekân açısından mobilize sahne kullanan bir tür olarak bu oyunlarda dekor gibi unsurlar gelişmemiştir.

\section{Orta Oyununun Sosyolojik Yapısı ve Modern Sanata Etkisi}

Orta oyununun kişi kadrosunda yer alan tipler Osmanlı toplumun kozmopolit yapısının iz düşümüdür. Arap, Kürt, Ermeni gibi etnik temsillerin birer tip olarak oyunda dramatize edilmesi Osmanlının kültürel zenginliğinin dışavurumudur. Kültürel çeşitliliğin oyunda kendine yer bulması Osmanlı Devleti'nin bünyesinde barındırdığı etnik kesimlere olan yaklaşımını göstermektedir. Bu tipler sadece kültürel özellikleriyle değil sınıfsal özellikleriyle de öne çıkar. Kayserili Bakkal tipinin bir ticaret erbabı olan esnaf1 temsil etmesi manidardır. Tarihteki ticaret merkezlerinden ilki Asur ticaret kolonilerinin uğrak yeri olan bugünkü Kayseri'dir. Kayseri'nin bu özelliği bugün de halkın belleğinde yer etmekte ve bu kent ticaret yönüyle zihinlerde eşleşmektedir. Aynı şekilde Acem halı tüccarı tipi de bu bağlamda değerlendirilebilir. Orta oyununun kısıtlı dekor elemanlarından olan "yenidünya" ve "dükkân" da ticaret konusunda önemli bir göstergedir: "Yenidünya" evi, "dükkân" ise iş yerini temsil etmektedir.

Toplumun değişik katmanlarından tiplere yer verilmesi oyunun gerçekçi yönünü güçlendirmektedir. Halkın tek yönlü olmadığı bir gerçektir. Halkın içindeki kabadayılar oyuna Tuzsuz Deli Bekir, sarhoşlar Matiz, züppeler Çelebi olarak aksetmektedir. Sanat eserlerinin üretildiği dönemin şartlarından bağımsız düşünülemeyeceği gerçeğini kriter alırsak mevcut zihniyetin ve toplumsal şartların orta oyununa yansıması da kaçınılmazdır.

Farklı etnik temsillerin orta oyununda yer alması bu türün 1789 Fransız İhtilali öncesinde şekillenmiş olmasından mütevellittir. Modernliğin sürdürülmesinde en önemli taşıyıcı etkenlerden biri ulus devletlerdir (Giddens, 2016). Bu ihtilal sonrası Avrupa'da başlayan etnik ayrışmalar ve imparatorlukların parçalanması Osmanlıya da çeşitli etnik kesimlerin isyanı şeklinde aksetmiştir. Türün gitgide önemini yitirmesindeki en önemli etkenlerden biri modernleşme ve modernleşmenin temsilcisi olan Batı'nın Osmanlı 
aydınlarınca örnek alınmasıdır. Modernliğin dönüşümü çerçevesinde anonim olan oyunlar müellifi belli oyunlarla tahvil edilmiştir. Türk edebiyatında müellifi belli oyunlar modernleşme sürecinin ürünüdür. Yazar, her ne kadar içinden çıtı̆̆1 toplumun zihniyetinden izler taşısa da ürettiği eser kendi zihninin ürünüdür. Bu bağlamda geleneksel olan kolektif zihnin, modern olansa bireyin yani tekil zihnin ürünüdür. Tekil olanın bütünü yansıtması imkânsızdır. Modern olan, yazılı olanın pratiğe dökülmesinden ibarettir; sınırları önceden belirlenmiş ve yazıyla güvenceye alınmıştır. Modern tiyatroda oyuncuya ezberlemesi için bir metin (text) verilirken orta oyununda oyuncuya rolünün anlatılması Doğu medeniyetlerinde sözlü geleneğin hüküm sürmesinden kaynaklı olabilir. Modernliğin bireyi sıkıştırması, onun pratik alanını önceden yasalarla belirlemesi modern sanatın da yüz yüze geldiği bir gerçektir. Geleneksel oyun türlerinde profesyonellik değil ustalık geçerlidir ve bu ustalık sosyal öğrenme ilkeleri çerçevesinde yaşamın içinde yani ortada/meydanda filizlenir.

İlk Müslüman Türk kadın oyuncu olan Afife Jale 1919'da Yamalar oyununda görülmüştür. Osmanlının şeri hukuk yapısı içinde Müslüman kadınların temaşa etmesi sakıncalıdır. Cumhuriyet ile kadınlar da erkekler gibi tiyatro oyuncusu olmuş ve sanat alanında sahneye erkeklerle eşit şekilde çıkmışlardır. Bu bağlamda Karagöz ve orta oyununda kadın karaktere rastlayamayız. Toplumu oluşturan iki cinsiyetten biri olan kadınlar oyunda vardır fakat kadın oyuncu olarak değil kadın kılığına girmiş erkek yani "Zenne" olarak oyunda yer almaktadır. "Zenne, kadının tarihî serüvenine bakıldığında kadının çeşitli yasaklarla baskılandığı dönemlerde üretilen bir çözüm arayışının sonucunda ortaya çıkmıştır. Bu nedenle de kadınlar yüzyıllar boyunca kendilerini erkeklerin gözünden seyretmişlerdir" (Kılıç, 2004, s. 178). Zennenin temsil ettiği roller incelendiğinde Osmanlı toplumundaki kadın algısının kategorilerine de ulaşılabilmektedir. Bu bağlamda bu zenne tipi hafif meşrep kadın, ev kadını, romantik âşık kadın ve cadı kadın rollerine bürünerek karşımıza çıkmaktadır (Kılıç, 2004). Türkiye'de özel kanalların artmasıyla doksanlı yılların ortalarında, akşam kuşağı televizyon programlarında da "zenne" tipi görülmeye başlamıştır: Huysuz Virjin, "zenne" tipinin günümüze yansımasıdır.

Oyuncuların izleyici önünde hesap verebilir olması toplumsal manada şeffaflık ilkesi açısından değerlendirilebilir. Yargılama meydanda yapılacağı için yargıyı verecek esas özne olan halk da sahneye girmektedir. Weberyan rasyonel bürokrasinin dramatik temsili orta oyununun bu özelliğinde bulunabilir. Richard Sennett (2016) sanayi öncesi toplumda tiyatroya izleyicinin müdahale edebildiğini fakat kamusal yaşamın kapitalist sistemin egemenliğine girerek modernleşmesiyle bu müdahalenin ilkellik sayıldığına dikkat çeker. Orta oyununun yargılama/mahkeme usulleriyle olan ilişkisi, Johan Huizinga'nın oyun kavramına yönelik görüşleriyle örtüşmektedir; oyun kavramı düzen yaratır ve düzenin kendisine dönüşür:

Efsane ile ibadetin kaynaklarından kültür hayatının büyük faaliyetleri doğmaktadır: düzen ve hukuk, ticaret ve endüstri, sanat ve zanaat, şiir, bilgelik ve bilim. Demek ki bunların köklerinin bir kısmı da oyunsal eylem alanındadır (...) Arena, oyun masası, sihirli çember, tapmak, sahne, perde, mahkeme; bunların hepsi biçim ve işlev açısından oyun alanlarıdır, yani tahsis edilmiş, ayrılmış, çevresine parmaklık çekilmiş, kutsallaştırılmış ve kendi sınırları içinde özel kurallara tabi kılınmış yerlerdir. Bunlar bildik dünyanın ortasında, belirli bir eylemin gerçekleştirilmesi amacıyla tasarlanmış geçici dünyalardır. Oyun alanının sinırları içinde kendine özgü ve mutlak bir düzen hüküm sürer. İşte oyunun daha da pozitif yeni bir çizgisi: Oyun düzen yaratır, oyun düzenin ta kendisidir (Huizinga, 2006, s. 21-28). 
Orta oyununun yeniçerilerin seferlerinde askerlere moral vermek için icra edilmesi, ava çıkarken yanında masalcı götürülmesi geleneğinin bir benzeridir. Akıl hastanelerinde hastalara şifa olması için bu oyunların sergilenmesi sağaltıcı işlev üstlendiğini göstermektedir. Aynı şekilde halkın bir araya gelerek bu oyunları izlemesi toplumsal dayanışma bağlarının güçlenmesini sağlayıp kişiler arası birlik duygusunu yüceltmektedir. Richard Sennett (2016) modern şehirleri eski rejimlerdeki şehirlerden farklı olarak değerlendirir ve onu yabancıların birbirleriyle karşılaştığı yer diye tanımlar. Osmanlı toplumunda bu modern şehirleşme ve kişiler arası mesafenin artması Tanzimat Dönemi ve sonrasına denk gelir. Osmanlıdaki modern tiyatrolar bu dönemde ortaya çıkmıştır. Sanatın sadece sanat olmadığı bazen şifa vermesi ve bazen askerlere moral desteği olması bazen de güldürürken düşündürmesi gibi toplumsal özellikleri orta oyununda görülmektedir. Aristo'nun işaret ettiği "katarsis" kavramı orta oyunu icrasında da devreye girmektedir. Ritüellere katılan insanların biriken enerjiyi boşaltmasını ve ilk tiyatroların ritüellerle ortaya çıktığını esas alırsak orta oyununun da ritüel gibi etkileri olduğu tespitinde bulunabiliriz.

Türklerin göçebe yaşam tarzı, İslamiyet'in etkisi ve Anadolu'da kurulan yerleşim birimlerine rağmen toplumsal zihinde ve belirli yaşam pratiklerinde kendini yeniden üreterek kesintisiz bir şekilde günümüze kadar ulaşmıştır. Bu yaşam tarzının etkilediği bir tiyatro türü de orta oyunudur. Türün bir sunma biçimi olduğu (Bauman, 2003) önermesinden hareketle orta oyununun meydanda oynanmasının yerleşik yaşamın değil göçebeliğin etkisine işaret ettiğini iddia edebiliriz. Yerleşik hayat, yazılı kanunlarla sınırlandırılmış kurumlaşmayı ve idari bürokrasiyi beraberinde getirmektedir. Orta oyunu modern tiyatrodan farklı olarak kendini temsil edebileceği sabit bir mekâna/kuruma sahip değildir. Orta oyunu kurumlaşmayı değil gelenekselliği temsil eder. İçinden çıktığı toplumun göçebeliği, orta oyununun temsilini de göçebeleştirmiştir. Modern kurumların en önemli özelliği yazılı normlara dayanmasıdır. Orta oyununun yazılı bir metninin olmaması yani sözlü geleneğin üretim biçimi olması Türk toplumunda göçebeliğin sanat alanında yeniden üretilmesinin dişavurumudur. Osmanlı toplumunda ilk canlandırılan modern oyunlar düşünüldüğünde bunların merkezinin İstanbul yani devletin başkentinde olduğunu ve tiyatronun da burada kurumlaşmaya başladığını unutmamak gerekir. Modern olan okullaşmayı gerektirirken orta oyununda ustalıkçıraklık uygulaması geçerlidir, bu türün oyuncusu usul ve erkân çerçevesinde kendini geliştirir. Daha önce değinildiği gibi orta oyunu oyuncuları günümüz "profesyonel" tiyatro oyuncuları gibi oyunculuğu meslek edinen kişiler değillerdir. Bu da geleneksel Türk tiyatrosu oyuncularının birer meslek erbabı olmadığını gösterir. Onlarda ustalaşma esasken günümüz mesleklerinde profesyonelleşme etkilidir.

Orta oyununda modern tiyatro türlerinden olan dram ve trajedi gibi sınıflandırmalar görülmez. Banu Ayten Akın'ın -orta oyununu da kapsayacak şekildegeleneksel Türk tiyatrosuna yaklaşımı, orta oyununun yazılı bir metni olmadı̆̆ından iktidarın cezasından kaçabildiği yönündedir ve ona göre bu türün komedi biçiminden öteye geçememesinin izahı şu şekildedir: "İktidarın ya da dinsel erkin, alt kültürün bir direniş biçimi olan mizah çerçeveli bu oyunlara izin vermesine rağmen; bu oyunların, kendilerinden Batı'daki gibi bir dram doğuramaması, toplumsal yapının ve düşüncenin laikleşip tanrılara kafa tuttuğu Yunan tragedyalarındaki gibi bir gelişimi izleyememesinden kaynaklanmaktadır" (Akın, 2013, s. 41). Bu oyunda güldürme unsuru ön plandadır. Orta oyununda söz komiği sayıca fazla yer tutar, yine bu durumun sebebi bu oyunların sözlü kültürün ürünleri olmasıdır (Ünlü, 2019). Kissadan hisse, gülmece unsurunun içinde eritilerek izleyicilere iletilmeye çalışlır. Böyle bir yöntemin izlenmesi savaşç1-göçebe bir toplumda cephe gerisi kabul edeceğimiz alan olan toplumsal yaşamda moralin yüksek tutulması açısından önemlidir. Nihal Türkmen'in $(1971$, s. 80) işaret ettiği 
gibi oyunların çoğunun “Ey gaziler, yol göründü!" diye başlayan -mehter takımı tarafından da çalındığı unutulmadan- türküyle bitirilmesi topluma moral verme açısından anlamlıdır. Gülmenin toplumsal yönüne John Morreal'in -sanatsal çerçevedeyaklaşımı şu şekildedir:

Mizah, aslında tıpkı diğer insani zevkler gibi toplumsal bir olgudur hatta başkalarıyla birlikteyken bizi güldürebilen birçok şeye, yalnızken çok seyrek güleriz. Bir topluluk içindeyken bir şeyi eğer yalnızca biz komik buluyorsak genellikle ağzımızı kapatır; gülüşümüzü, en azından diğerleri bize katılana kadar engellemeye çalışırız. Gülmenin toplumsal boyutu da onun bulaşıcı olduğunu gösterir. Gülmek, grup hâlindeyken bir füzyon reaksiyonu gibi yayılır (...) Komedyenler ve tiyatrocular, bir salon dolusu insanı güldürmenin yarısı dolu olan salondakileri güldürmekten daha kolay olduğunu iyi bilirler (Morreal, 1997, s. 160).

Orta oyununun bu yönleri Türk sinemasinda Kemal Sunal ve Şener Şen filmlerinde de görülmektedir. Bu filmlerde komedi unsurunun eleştirel bir misyonu vardır. Franco Moretti (2005) edebî türlerin tıpkı doğadaki evrimsel süreç gibi gelişime sahip olduğunu savunarak her türün bir önceki türden etkilendiğini ve ondan izler taşıdığını öne sürer. Ceyda Emel Öztek Kanlı Nigar'ın sinemaya uyarlanışında ve Şabanoğlu Şaban gibi tiplemelerin yaratılmasında orta oyununun etkisi olduğunu savunarak orta oyununun Yeşilçam'ı da içine alarak Türk sinemasına yansımasını şu şekilde tarif etmiştir:

Yeni icat sinemanın gelmesiyle halkın daha önce Karagöz, kukla ve orta oyunu gibi geleneksel halk tiyatrosunu izlediği alanlar ve mekânlar yerlerini beyaz perdeye bırakır. Ferah Tiyatrosu, Millet Tiyatrosu, Turan Tiyatrosu o dönemlerde sinema salonlarına dönüşmeye başlar. $\mathrm{Bu}$ geçiş döneminde halktaki ve sanatçılardaki yerleşik olan seyir alışkanlıkları ve üretim tarzları da Türk sinemasındaki ilk filmlere yansır. Halkın izlediği bu ilk seyirlikler genellikle toplumdaki aksaklıkları veya bu durumların sonuçlarını ibretiâlem hikâyeleriyle anlatır. Bu nedenle orta oyunun kimi kodlarının güldürü filmlerine yansıdığı savunulabilir (Öztek, 2019, s. 970-71).

Orta oyununun millî bir tür olması, Batılı tarzdaki tiyatro eserlerinden günümüz Türk sineması filmlerine kadar etkilemesi de dramatik sanat geçmişimiz açısından bir kök niteliği taşımaktadır. Orta oyunu Türk televizyon kanallarında akşam kuşağı kapsamında yayınlanan komedi programlarını da etkilemiştir. Yıllardır çeşitli kanallarda oynatılan Komedi Dükkânı programı ile orta oyunu arasında dekor, oyuncu ekibi ve kullanılan yöntemler bakımından benzerlik kuran çalışmalar literatürde mevcuttur (Uçar ve Koca, 2011).

Orta oyunu sadece Türk sinemasında değil modern Türk şiirinde de etkisini göstermiştir. İkinci Yeni şairlerinden Ece Ayhan'ın şiirlerinde bu etkiler izlenebilir (Deveci, 2018). Ece Ayhan cambazları, kantocuları ve orta oyununun unsurlarını şiirine taşımıştır. Şiirin folklora düşman olduğu tartışmasından hareketle Ece Ayhan'ın bu indirgemeci görüşün karşısında olduğu görülmektedir. Franco Moretti'nin (2005) işaret ettiği "bastırılanın geri dönüşü" kapsamına giren geleneksel unsurlar cinsiyetçi söylemin eleştirisi şeklinde "zenne" tipi üzerinden Ece Ayhan şiirinde zuhur etmiştir:

$X$

\section{ORTA OYUNU}

1. Erkek hastalar kadın, kadınlar erkek kılığındadır; Mehmet 
Akif Paşa günlüğünü yazarken şahnişinde.

2. Topluluğu bulmak için başhekime başvurunuz! (Ayhan, 2019, s. 216).

\section{Sonuç}

Orta oyununun şekil özellikleri ve tarihinden yola çıkılarak onun sosyolojik yapısının ve modern sanata etkilerinin incelendiği bu çalışmada orta oyunun çeşitli özellikleri hakkında tespitler yapıldı. Türklerin göçebe yaşam tarzının bu türü etkilediği sahne ve dekor özelliklerinin mobilize olmasını sağladığı görülmektedir. Sözlü geleneğin etkisiyle yazılı bir metne sahip olmayan orta oyunu eleştirel mizahı kullandığından sansür ve baskı aygıtlarının kapsam alanı dışına çıkmaktadır. "Söz uçar, yazı kalır." ekseninde değerlendirildiğinde sarf edilen eleştirel sözlerin de ispatı yapılamamaktadır. Orta oyununa özgürlük alanı sağlayan diğer bir unsur da sahne olarak sınırı belli olmayan bir meydanın kullanılmasidır. Orta oyunu toplumu bir araya getirmesi, savaşlarda orduya gösterimler yapması veçheleriyle hem cephede hem de cephe gerisinde halka moral desteği sağlamaktadır. Oyundaki kişilerin farklı etnik kimliklerden ve sinıflardan gelmesi Osmanlı toplum yapısının bir meydanda dramatize edilmesi açısından önemlidir. Oyunda bir kadın karakterin erkek kılığına girmiş zenne tarafından canlandırılması ve bu tipin çeşitli kadın kişiliğinin temsillerini vermesi Osmanlı toplumundaki kadın algısını açı̆̆a çıkarması açısından anlamlıdır.

Kamusal yaşamın geleneksel pratikleri açısından orta oyununa bakıldığında bu türün modern tiyatro türlerinin karşısında konumlandığı görülmektedir. Modern tiyatro türleri bir sahneye sahip özel bir bina, profesyonellik ve bürokrasi gerektirirken orta oyunu usta-çırak ilişkisi, doğallık ve anti-bürokrasi özelliğine sahiptir. Modern yaşam tekil olanın yani bireyin pratiklerinde şekillenirken geleneksel yaşam yatay ilişkilerle toplumsal dayanışmayla biçimlenir. Bu bağlamda modern tiyatroda sessizliğin hâkim olduğu karanlık bir ortamda koltuk düzeni varken orta oyununda böyle bir durum yoktur. Orta oyununda izleyiciler açısından yatay ilişki hâkimdir; izleyiciler, oyuncuların etrafını çevirdiği meydanda hem oyuncuyla hem diğer izleyicilerle yüz yüze etkileşim hâlindedir. Oyun, yatay ilişkilerin hâkimiyetine verdiği destekle karnaval havasını aksettirmektedir. Modern tiyatroların temsil edilme aşamasında belirli bürokratik süreçlerden geçmesine karşın orta oyununda böyle bir bürokrasiden söz etmek neredeyse imkânsızdır. Günümüz pazar ilişkilerinden payını alan modern tiyatroların metalaşması gibi bir süreci, orta oyunu Osmanlı toplumunda hüküm sürdüğü dönemlerde yaşamamıştır.

Osmanlı şehirlerinin Batılılaşma/modernleşme etkisiyle kente dönüşme aşamasında orta oyunu gitgide geri plana itilmiştir. Günümüzde sadece kavuk değişimi pratiğiyle orta oyunu varlığını hissettirse de Cumhuriyet sonrasında birçok sanat dalını etkilemiştir. Güldürürken düşündüren yönleriyle Türk sinemasını, barındırdığı unsurların kullanımıyla modern Türk şiirini, şekil özellikleriyle Türk komedi televizyon programlarını etkilemiştir. Orta oyununun bazı gerçeküstü özellikleri sürrealizm akımından önce ortaya çıkmıştır. Oyuncuların izleyiciye hesap verebilir olması Weber'in akılcı bürokrasinin çağlar öncesinden dramatize edilmesi gibidir. Orta oyunu modernite tarafından kıskaca alınmış bir tür olmasına rağmen modern sanatı da etkilemiştir, bu yönüyle moderniteyle karşılıklı etkileşim içindedir.

\section{Kaynakça}

Akın, B. A. (2013). Osmanlıda İslami Hükümlerin Belirleyiciliğinde Varolabilen Gösteri Türleri: Meddah, Karagöz ve Orta Oyunu. Journal of World of Turks, 5(2), 33-42.

Alus, S. M. (1950). Eski Milli Tiyatromuz: Orta Oyunu. Resimli Tarih Mecmuası, 7, 266-268. 
And, M. (1985). Geleneksel Türk Tiyatrosu. İstanbul: İnkılap Yayınları.

Ayhan, E. (2019). Bütün Yort Savul'lar!. İstanbul: Yapı Kredi Yayınları.

Balay, M. (2010). Osmanlı Modernleşmesi ve Orta Oyunu. Tiyatro Araştırmaları Dergisi, 30(30), 93-109.

Baltacioğlu, İ. H. (2021). Orta Oyunu. Fikir ve Sanat, http://dspace.marmara.edu.tr/bitstream/handle/11424/162577/001526633006.p df?sequence=3, [Erişim tarihi: 16.08.2021].

Bauman, R. (2003). Tür. Halkbiliminde Kuramlar ve Yaklaşımlar. (Çev. Hülya Seyhan Sipahioğlu). Ankara: Milli Folklor, 61-66.

Giddens, A. (2016). Modernliğin Sonuçları. (çev. Ersin Kuşdil). İstanbul: Ayrıntı Yayınları.

Huizinga, J. (2006). Homo Ludens: Oyunun Toplumsal İşlevi Üzerine Bir İnceleme. (çev. Mehmet Ali Kılıçbay). İstanbul: Ayrıntı Yayınları.

Kılıç, Ç. (2004). Geleneksel Türk Tiyatrosu'nda Zenne Tipi ve Orta Oyunu'nundaki Uygulamaları. Yüksek Lisans Tezi. İzmir: Dokuz Eylül Üniv.

Konur, T. (1995). Orta Oyunu. Tiyatro Araştırmaları Dergisi, 12(12), 47-51.

Moretti, F. (2005). Mucizevi Göstergeler: Edebi Biçimlerin Sosyolojisi Üzerine. (Çev. Zeynep Altok). İstanbul: Metis Yayınları.

Morreall, J. (1997). Gülmeyi Ciddiye Almak. (Çev. Kubilay Aysevener ve Şeynay Soyer). İstanbul: İris Yayınları.

Öztek, C. E. (2019). Türk Güldürü Filmlerinin Orta Oyunu Açısından İncelenmesi. Turkish Studies, 14(3), 963-971.

Sennet, R. (2016). Kamusal İnsanın Çöküşü. (Çev. Serpil Durak ve Abdullah Yılmaz). İstanbul: Ayrıntı Yayınları.

Türkmen, N. (1971). Orta Oyunu. İstanbul: Milli Eğitim Yayınları.

Uçar, A. ve Koca, C. (2011). Görme Düzleminde Komedi Dükkânı ile Orta Oyunu Arasındaki Bağ ve Dilsel Komik (Söz Komiği) Açısından Bir Karşılaştırma. Dil ve Edebiyat Dergisi, 8(2), 39-63.

Ümral, D. (2018). Ece Ayhan'ın Şiirlerinde Masalsı Değiştirimler. Anemon Muş Alparslan Üniversitesi Sosyal Bilimler Dergisi, 6(5), 655-660.

Ünlü, E. (2019). Karagöz ve Orta Oyununda Mizah. Yüksek Lisans Tezi. Muğla: Muğla Sitkı Koçman Üniv.

Zobu, V. R. (2021). Orta Oyunu, http://dspace.marmara.edu.tr/bitstream/handle/11424/133344/001580639010.p df?sequence=3, [Erişim tarihi: 04.06.2021]. 